\title{
Health problems among employees in small enterprises as a result of improper OHS management
}

\author{
Marta Niciejewska $^{1, *}$, and Dorota Klimecka-Tatar ${ }^{1}$ \\ ${ }^{1}$ Czestochowa University of Technology, Department of Production Engineering and Safety, \\ ul. Armii Krajowej 19 B, 42-200 Czestochowa, Poland, EU
}

\begin{abstract}
Occupational health problems are rarely underestimated both by employers and employees themselves. Lack of awareness about the impact of the environment on the health of the human body results in more frequent accidents, the sources of which are seen in the health problems of employees. Lifestyle, as well as the management of occupational health and safety, affect work quality and safety. It this paper ailments that have a significant impact on the health of the employee, which are the result of improper management of occupational safety and health in small enterprises, have been presented. The obtained results also indicate factors that cause various health problems among employees, with particular emphasis on stress symptoms.
\end{abstract}

\section{Introduction}

Health problems resulting from work may have a different origin. The literature on the subject indicates a whole range of threats that negatively affect the health and even the life of the employee - in the physical, biological, chemical and psychosocial areas [1-3]. Taking into account the level of occupational safety as well as health care in enterprises, it can be stated that all health-related problems are due to the employee's insufficient working conditions, but also to the lack of awareness of safe work [4-6]. To the most frequently indicated health problems associated with professional work include musculoskeletal disorders [5,7-9]. According to numerous reports and publications musculoskeletal disorders are the most widespread health-related problems. Almost $24 \%$ of employees from EU countries complain about back pain, and 22\% - for muscle pain. These diseases are more common in the new Member States, with 39 and 36\% respectively. Musculoskeletal disorders do not only cause physical suffering and loss of income in the individual dimension, but they are also costly for businesses and the economy in general. Although they can occur with every employee, they can be effectively prevented by assessing the professional activities performed and by introducing appropriate preventive measures and controlling their effectiveness [10]. In Poland, the Central Statistical Office also indicates musculoskeletal disorders as those that are the most common among employees of the

*Corresponding author: marta.niciejewska@,wz.pcz.pl 
following three sectors: health care, transport, trade as well as professional builders. The reasons are not seen only in the hazards of the working environment, but also in the phenomenon of increased work time. Work often dominates in human life, and the lack of balance between work and private life results in health problems [1,11]. Time pressure causes; that employees forget about individual health prophylaxis, e.g. basic blood control tests, cholesterol levels, a balanced diet, outdoor activities. In addition, the sedentary nature of the work, as well as the non-ergonomically designed work place result in the occurrence of musculoskeletal disorders, exposure to noise generates irritability and headaches, and the disorder of interpersonal relationships in turn creates a sense of burnout and stress [13-15]. Consequently, these factors can contribute to the creation of dangerous occupational diseases.

The information from European Agency for Safety and Health at Work, EU-OSHA reports; that more often "hidden" threats, which include psychosocial risks and stress, have a decisive impact on human health. Psychosocial hazards arise from poor work planning, poor work organization and poor management, and from an unfavorable social work environment. They can lead to negative psychological, physical and social effects such as occupational stress, burnout or depression $[14,16]$. As with other issues related to mental health, the problem of stress is often misunderstood or stigmatized. The effect of psychosocial risks is reaching for stimulants - cigarettes, alcohol, antidepressants. They, in turn, generate further health problems among employees. However, it is difficult to determine which of these stimulators are only a reflection of the working conditions. There is a constant need, for employers to implement and for workers to compliance; preventive actions that will increase the level of safe working conditions [1].

\section{Methodology of research}

In this work, to achieve cognitive goals, the original questionnaire regarding assessment of factors that affect job security in small enterprises has been used. Respondents, in the number equal to 1006 came from small businesses - manufacturing, service, retail and mixed, survey questionnaires were filled out anonymously by employees (one questionnaire $=$ a single economic entity). For the presentation and careful analysis of the received data the statistical methods have been used. Data are presented in nominal and ordinal scale. There were used mainly structural indicators, correlation analysis using the coefficient tauKendall, $\chi 2$ test of independence and $\varphi$ - Yule correlation coefficient. In the field of mathematical statistics, the Mann-Whitney test was used as an alternative to the medium test.

\section{Results and discussion}

During the survey, the respondents had to indicate in the questionnaire which of the mentioned ailments, in their opinion, are related to the work performed on a daily basis. The obtained results are presented in Tables 1-6 (according to the average). In Table 1 a distribution of indicated factors is presented which, in the opinion of respondents, most often occur in work conditions - according to the sector of activity. Respondents did not indicate high significance of the arduous working conditions effects. The maximum average rating was 3.145 for musculoskeletal disorders. In each case, the assessment for the manufacturing enterprises sector was higher than the ratings of the service sector. Significant differences were noted for assessments of musculoskeletal disorders $(Z=2.252$, $\mathrm{p}=0.024)$, symptoms of chronic fatigue $(Z=7.358, \mathrm{p}<0.001)$ and burnout $(Z=5.103, \mathrm{p}$ $<0.001)$. In this aspect, physical fatigue associated with the production sector generates 
higher ratings. In the other hand monotonous work inhibits creativity and in the long run causes burnout.

Table 1. Distribution of indications of the effects of arduous work conditions occurring most often in the opinion of respondents and the results of the the Mann-Whitney test significance of differences between the production and service sector $(\alpha=0.05)$.

\begin{tabular}{|c|c|c|c|c|c|c|c|c|}
\hline $\begin{array}{c}\text { Consequences of } \\
\text { arduous work } \\
\text { conditions }\end{array}$ & \multicolumn{4}{|c|}{ Average rating in enterprises } & \multirow{2}{*}{ Median } & \multicolumn{3}{c|}{$\begin{array}{c}\text { Rezults } \\
\text { of M-W test }\end{array}$} \\
\cline { 2 - 7 } \cline { 8 - 10 } & Production & Service & Trade & Mixed & Total & & Z & P \\
\hline $\begin{array}{c}\text { Musculoskeletal } \\
\text { disorders }\end{array}$ & 3.207 & 3.132 & 3.000 & 3.129 & 3.145 & 3.000 & 2.252 & 0.024 \\
\hline Chronic fatigue & 2.751 & 2.368 & 2.778 & 2.621 & 2.510 & 2.000 & 7.358 & 0.000 \\
\hline Burnout & 2.390 & 2.178 & 2.500 & 2.293 & 2.256 & 2.000 & 5.103 & 0.000 \\
\hline $\begin{array}{c}\text { Cardiovascular } \\
\text { disease }\end{array}$ & 2.212 & 2.156 & 2.250 & 2.250 & 2.186 & 2.000 & 1.506 & 0.132 \\
\hline
\end{tabular}

The distribution of the most frequent indications according to musculoskeletal disorders is presented in Table 1.2. Respondents did not indicate very important reasons for musculoskeletal disorders. Repeated activities $(Z=3.621, p<0.001)$, non-ergonomic work positions $(Z=3.115, \mathrm{p}<0.001)$ and forced work position $(Z=1.977, \mathrm{p}=0.048)$ were clearly indicated as important in production enterprises. Manual transport of materials was rated as higher by the employees of service industry service $(Z=-4,336, p<0.001)$. In the service sector, which is more often associated with white-collar workers, manual material transport seems to be too heavy work, which cannot be said about the production sector.

Table 2. Distribution of indications of the couses of musculoskeletal disorders occurring most often in the opinion of respondents and the results of the the Mann-Whitney test significance of differences between the production and service sector $(\alpha=0.05)$

\begin{tabular}{|c|c|c|c|c|c|c|c|c|}
\hline $\begin{array}{c}\text { Couses for } \\
\text { musculoskeletal } \\
\text { disorders }\end{array}$ & \multicolumn{4}{|c|}{ Average rating in enterprises } & \multirow{2}{*}{ Median } & \multicolumn{3}{c|}{$\begin{array}{c}\text { Rezults } \\
\text { of M-W test }\end{array}$} \\
\cline { 2 - 6 } \cline { 8 - 10 } & Production & Service & Trade & Mixed & Total & & Z & P \\
\hline Repeated activities & 3.241 & 3.100 & 2.750 & 3.093 & 3.120 & 3.000 & 3.621 & 0.000 \\
\hline $\begin{array}{c}\text { Incorrect work } \\
\text { position }\end{array}$ & 3.029 & 2.963 & 2.667 & 2.736 & 2.936 & 3.000 & 1.406 & 0.160 \\
\hline $\begin{array}{c}\text { Forced position at } \\
\text { work }\end{array}$ & 3.062 & 2.975 & 2.917 & 2.936 & 2.988 & 3.000 & 1.977 & 0.048 \\
\hline $\begin{array}{c}\text { Manual transport } \\
\text { of materials }\end{array}$ & 2.656 & 2.980 & 2.750 & 2.550 & 2.834 & 3.000 & 4.336 & 0.000 \\
\hline $\begin{array}{c}\text { Non-ergonomic } \\
\text { work station }\end{array}$ & 2.572 & 2.358 & 2.389 & 2.143 & 2.370 & 2.000 & 3.115 & 0.002 \\
\hline
\end{tabular}

In table 3 a distribution of indications of the effects of arduous work conditions was presented, which occur most often in the opinion of respondents according to their age. Between the impact assessments arduous working conditions and the age of the respondents there are weak, statistically significant positive correlations. They concern the assessment of the significance of musculoskeletal disorders ( $\mathrm{r} \tau=0.105, \mathrm{p}<0.001$ ), symptoms of chronic fatigue $(\mathrm{r} \tau=0.140, \mathrm{p}<0.001)$, symptoms of burnout $(\mathrm{r} \tau=0.073, \mathrm{p}=0.001)$ and cardiovascular disease $(\mathrm{r} \tau=0.141, \mathrm{p}<0.001)$. With age, the assessment of the significance of these ailments increases. 
Table 3. Distribution of indications of the effects of arduous work conditions occurring most often in the opinion of respondents and the value of the tau-Kendall correlation coefficient between the age of musculoskeletal disorders $(\alpha=0.05)$

\begin{tabular}{|c|c|c|c|c|c|c|c|c|c|}
\hline \multirow{2}{*}{$\begin{array}{c}\text { Consequences } \\
\text { of arduous work } \\
\text { conditions }\end{array}$} & \multicolumn{6}{|c|}{ Age } & \multirow[b]{2}{*}{ Total } & \multicolumn{2}{|c|}{ Correlation } \\
\hline & $18-24$ & 25-34 & $35-44$ & $45-54$ & $55-64$ & $\begin{array}{l}65 \text { and } \\
\text { more }\end{array}$ & & Tau & $\mathrm{P}$ \\
\hline $\begin{array}{c}\text { Musculoskeletal } \\
\text { disorders }\end{array}$ & 2.841 & 2.722 & 3.168 & 3.218 & 3.273 & 3.250 & 3.145 & 0.105 & 0.000 \\
\hline Chronic fatigue & 2.638 & 2.051 & 2.469 & 2.621 & 2.909 & 3.250 & 2.510 & 0.140 & 0.000 \\
\hline Burnout & 2.174 & 1.871 & 2.346 & 2.242 & 2.333 & 3.250 & 2.256 & 0.073 & 0.001 \\
\hline $\begin{array}{c}\text { Cardiovascular } \\
\text { disease }\end{array}$ & 2.087 & 1.847 & 2.139 & 2.321 & 2.303 & 2.750 & 2.186 & 0.141 & 0.000 \\
\hline
\end{tabular}

Table 3 presents the results concerning the distribution of indications of the causes of musculoskeletal disorders, which occur most often, in the respondents' opinion, relatively to their age. There are weak, statistically significant positive links between the assessment of the causes of musculoskeletal disorders and the respondents' age. They concern the assessment of the causes of musculoskeletal disorders such as: frequent repetitive activities $(\mathrm{r} \tau=0.108, \mathrm{p}<0.001)$, incorrect position at work $(\mathrm{r} \tau=0.078, \mathrm{p}<0.001)$, forced position at work $(\mathrm{r} \tau=0.102, \mathrm{p}<0.001)$, manual material transport $(\mathrm{r} \tau=0.100, \mathrm{p}<0.001)$ and nonergonomically designed and equipped work stations $(r \tau=0.077, \mathrm{p}<0.001)$. With age, the assessment of the importance of these reasons increases.

Table 4. Distribution of indications of the couses of musculoskeletal disorders occurring most often in the opinion of respondents and the value of the tau-Kendall correlation coefficient between the age of musculoskeletal disorders $(\alpha=0.05)$

\begin{tabular}{|c|c|c|c|c|c|c|c|c|c|}
\hline $\begin{array}{c}\text { Consequences } \\
\text { of arduous work } \\
\text { conditions }\end{array}$ & $18-24$ & $25-34$ & $35-44$ & $45-54$ & $55-64$ & $\begin{array}{c}65 \text { and } \\
\text { more }\end{array}$ & Total & Tau & $\mathrm{P}$ \\
\hline $\begin{array}{c}\text { Repeated } \\
\text { activities }\end{array}$ & 2.870 & 2.733 & 3.076 & 3.222 & 3.364 & 3.500 & 3.120 & 0.108 & 0.000 \\
\hline $\begin{array}{c}\text { Incorrect work } \\
\text { position }\end{array}$ & 2.725 & 2.522 & 2.969 & 2.966 & 3.242 & 3.250 & 2.936 & 0.078 & 0.000 \\
\hline $\begin{array}{c}\text { Forced position } \\
\text { at work }\end{array}$ & 2.725 & 2.561 & 3.024 & 3.024 & 3.273 & 4.000 & 2.988 & 0.102 & 0.000 \\
\hline $\begin{array}{c}\text { Manual transport } \\
\text { of materials }\end{array}$ & 2.391 & 2.443 & 2.890 & 2.925 & 2.758 & 2.750 & 2.834 & 0.100 & 0.000 \\
\hline $\begin{array}{c}\text { Non-ergonomic } \\
\text { work station }\end{array}$ & 2.246 & 2.063 & 2.353 & 2.406 & 2.636 & 3.000 & 2.370 & 0.077 & 0.000 \\
\hline
\end{tabular}

In the study, respondents made indications of stress symptoms that occur most frequently in their lives and are equated with work. Table 5 presents results on the distribution of stress symptoms, which most often appear, in the opinion of respondents, relatively to their age. There is a positive weak correlation between age and stress symptoms such as $\div$ increased blood pressure $(\mathrm{r} \tau=0.050, \mathrm{p}=0.018)$, increased cholesterol $(\mathrm{r} \tau=0.146, \mathrm{p}<0.001)$, anger $(\mathrm{r} \tau=0.077, \mathrm{p}<0.001)$ and smoking $(\mathrm{r} \tau=0.120, \mathrm{p}<0.001)$. With age, the assessment of the significance of these symptoms of stress increases. There was also a negative statistically significant correlation between age and the assessment of stress symptoms such as: depression $(\mathrm{r} \tau=-0,050, \mathrm{p}=0.017)$, absenteeism at work $(\mathrm{r} \tau=$ $0.0545, \mathrm{p}=0.011)$ and desire to change job $(\mathrm{r} \tau=-0.190, \mathrm{p}<0.001)$. Older employees have a decidedly less willingness to change their job and, partly because of the fear, they try to not abuse absenteeism. 
Table 5. Distribution of indications of stress symptoms occurring most often in the opinion of respondents according to the age of respondents, and the value of the correlation coefficient of tau-Kendall between age and stress symptoms $(\alpha=0.05)$

\begin{tabular}{|c|c|c|c|c|c|c|c|c|c|}
\hline $\begin{array}{c}\text { Consequences } \\
\text { of arduous work } \\
\text { conditions }\end{array}$ & $18-24$ & $25-34$ & $35-44$ & $45-54$ & $55-64$ & $\begin{array}{c}65 \text { and } \\
\text { more }\end{array}$ & Total & Tau & $\mathrm{P}$ \\
\cline { 5 - 8 } \cline { 5 - 9 } $\begin{array}{c}\text { Increased blood } \\
\text { pressure }\end{array}$ & 2.377 & 2.153 & 2.380 & 2.474 & 2.576 & 3.000 & 2.429 & 0.050 & 0.018 \\
\hline $\begin{array}{c}\text { Acceleration of } \\
\text { heart rate }\end{array}$ & 2.406 & 2.231 & 2.432 & 2.491 & 2.636 & 3.000 & 2.478 & 0.024 & 0.248 \\
\hline $\begin{array}{c}\text { Increased } \\
\text { cholesterol }\end{array}$ & 1.899 & 1.890 & 2.207 & 2.317 & 2.212 & 2.500 & 2.205 & 0.146 & 0.000 \\
\hline Anger & 2.551 & 2.071 & 2.437 & 2.502 & 2.697 & 3.250 & 2.455 & 0.077 & 0.000 \\
\hline Anxiety & 2.145 & 1.827 & 2.089 & 2.061 & 2.152 & 2.500 & 2.084 & 0.012 & 0.559 \\
\hline Depression & 1.971 & 1.851 & 2.037 & 1.997 & 1.939 & 2.000 & 2.031 & -0.050 & 0.017 \\
\hline Smoking & 2.362 & 2.349 & 2.647 & 2.802 & 2.879 & 3.500 & 2.687 & 0.120 & 0.000 \\
\hline Alcohol abuse & 2.043 & 1.867 & 2.215 & 2.048 & 2.152 & 2.750 & 2.132 & -0.015 & 0.464 \\
\hline Insomnia & 2.188 & 2.051 & 2.241 & 2.263 & 2.424 & 2.750 & 2.270 & 0.028 & 0.187 \\
\hline $\begin{array}{c}\text { Absenteeism at } \\
\text { work }\end{array}$ & 2.043 & 1.831 & 2.073 & 2.020 & 1.970 & 2.000 & 2.053 & -0.054 & 0.011 \\
\hline $\begin{array}{c}\text { Tendency to } \\
\text { make mistakes }\end{array}$ & 2.275 & 1.882 & 2.113 & 2.205 & 2.121 & 2.500 & 2.157 & 0.024 & 0.259 \\
\hline $\begin{array}{c}\text { The desire to } \\
\text { change jobs }\end{array}$ & 2.507 & 2.235 & 2.387 & 2.191 & 2.242 & 2.500 & 2.367 & -0.190 & 0.000 \\
\hline
\end{tabular}

Table 6. Distribution of indications of stress symptoms occurring most frequently in the opinion of respondents by the sector of activity, as well as results of the test of significance of differences between the indications for the production and service sector $(\alpha=0.05)$

\begin{tabular}{|c|c|c|c|c|c|c|c|c|}
\hline $\begin{array}{c}\text { Couses for } \\
\text { musculoskeletal } \\
\text { disorders }\end{array}$ & \multicolumn{4}{|c|}{ Average rating in enterprises } & \multirow{2}{*}{ Median } & \multicolumn{3}{c|}{$\begin{array}{c}\text { Rezults } \\
\text { of M-W test }\end{array}$} \\
\cline { 2 - 6 } & Production & Service & Trade & Mixed & Total & & Z & P \\
\hline $\begin{array}{c}\text { Increased blood } \\
\text { pressure }\end{array}$ & 2.510 & 2.365 & 2.444 & 2.557 & 2.429 & 2.000 & 2.457 & 0.014 \\
\hline $\begin{array}{c}\text { Acceleration of } \\
\text { heart rate }\end{array}$ & 2.556 & 2.390 & 2.611 & 2.679 & 2.478 & 2.000 & 3.382 & 0.001 \\
\hline $\begin{array}{c}\text { Increased } \\
\text { cholesterol }\end{array}$ & 2.137 & 2.248 & 2.222 & 2.136 & 2.205 & 2.000 & -3.634 & 0.000 \\
\hline Anger & 2.444 & 2.394 & 2.778 & 2.650 & 2.445 & 2.000 & 0.299 & 0.765 \\
\hline Anxiety & 2.066 & 2.061 & 2.417 & 2.129 & 2.084 & 2.000 & -0.597 & 0.551 \\
\hline Depression & 1.975 & 2.037 & 2.194 & 2.057 & 2.031 & 2.000 & -2.197 & 0.028 \\
\hline Smoking & 2.614 & 2.756 & 2.194 & 2.650 & 2.687 & 3.000 & -2.374 & 0.018 \\
\hline Alcohol abuse & 2.041 & 2.188 & 2.000 & 2.086 & 2.132 & 2.000 & -2.859 & 0.004 \\
\hline Insomnia & 2.187 & 2.324 & 2.389 & 2.157 & 2.270 & 2.000 & -3.160 & 0.002 \\
\hline $\begin{array}{c}\text { Absenteeism at } \\
\text { work }\end{array}$ & 2.062 & 2.051 & 2.083 & 2.036 & 2.053 & 2.000 & 0.478 & 0.633 \\
\hline $\begin{array}{c}\text { Tendency to make } \\
\text { mistakes }\end{array}$ & 2.170 & 2.129 & 2.528 & 2.157 & 2.157 & 2.000 & 1.141 & 0.254 \\
\hline $\begin{array}{c}\text { The desire to } \\
\text { change jobs }\end{array}$ & 2.386 & 2.312 & 2.889 & 2.429 & 2.367 & 2.000 & 0.417 & 0.677 \\
\hline $\begin{array}{c}\text { Increased blood } \\
\text { pressure }\end{array}$ & 2.510 & 2.365 & 2.444 & 2.557 & 2.429 & 2.000 & 2.457 & 0.014 \\
\hline
\end{tabular}


Table 6 presents results on the distribution of stress symptoms; which occur, in the opinion of respondents, according to the indications of the sector of activity. The surveyed employees perceive possible symptoms of stress only to a limited extent - as significant or moderately significant. Nevertheless, there are significant differences in the assessment of these symptoms from the employees of the production and service sectors. In the service sector, the role of increased cholesterol is significantly higher $(Z=-3.634, p<0.001)$, insomnia $(Z=-3.160, p=0.002)$, alcohol abuse $(Z=-2.859, p=0.004)$, smoking $(\mathrm{Z}=-2.3374, \mathrm{p}=0.018)$ and depression $(\mathrm{Z}=-2.197, \mathrm{p}=0.028)$. On the other hand, the production sector more often sees symptoms of stress such as acceleration of heart rate $(Z=3.382, p=0.001)$ and increased blood pressure $(Z=2.457, p=0.014)$.

\section{Summary}

Health prevention activities in the workplace; elaborated among others by EU-OSHA are available for every enterprise. Unfortunately, in the smallest business entities this subject is downplayed and often overlooked. Based on the presented results it can be concluded that musculoskeletal disorders result mainly from the activities of a frequently repeated, nonergonomic workplace or forced body position during the performance of tasks; chronic fatigue and burnout are also a problem of a modern employee who works too hard and too hard in relation to the time spent on strength regeneration and rest; workload intensify the use of stimulants, which seemingly support professional performance and eliminate fatigue.

\section{References}

1. N. Ulutasdemir, M. Kilic, Ö. Zeki, F. Begendi, Ann. Glob. Health., 81, 503 (2015)

2. L.L. Schmitz, J. Health Econ., 50, 183 (2016)

3. J. Mullen, E.K. Kelloway, M. Teed, Safety Sci., 91, 405 (2017)

4. D. Klimecka-Tatar, M. Niciejewska, Production Engineering Archives, 13, 49 (2016)

5. P. Arezes, F. Serranheira, Int. J. Ind. Ergonom., 60, 1 (2017)

6. Y. Kim, J. Park, M. Park, Saf .Health Work, 7, 89 (2016)

7. https://oshwiki.eu/wiki/Risk_factors_for_musculoskeletal_disorders_development:_ha nd-arm_tasks, EUOSHA.

8. L.E. Charles, C. C. Ma, C. M. Burchfiel, R. G. Dong, Saf .Health Work (to be published)

9. Z.G. d. Santos, L. Vieira, G. Balbinotti, Procedia Manufacturing, 3, 5947 (2015)

10. J. Costa-Font, M. Ljunge, Econ. Hum. Biol., 28, 119 (2018)

11. M.E. Major, N. Vézina, Int. J. Ind. Ergonom., 48, 149 (2015)

12. D.J. Weber, W. A. Rutala, Infect. Dis. Clin. N. Am., 30, 729 (2016)

13. V. Schiele, H. Schmitz, J. Health. Econ., 49, 59 (2016)

14. T. Rosenthal, A. Alter, J. Am. Soc. Hypertens., 6, 2 (2012)

15. K. Hirokawa, T. Ohira, M. Nagayoshi, M. Kajiura, H. Imano, A. Kitamura, M. Kiyama, T. Okada, H. Iso, Preventive medicine reports, 4, 61 (2016)

16. M. Gavrilă-Ardelean, O. D. Moldovan, Procedia - Social and Behavioral Sciences, 159, 589 (2014)

17. Pacana, R. Ulewicz, Polish Journal of Management Studies, 16, 165-174 (2017) 